\title{
THE WORLD SEEN FROM PETERSBURG. SOME REMARKS ON THE GEOGRAPHICAL RANGE OF RUSSIAN POLITICIANS' INTERESTS AT THE BEGINNING OF THE 19th CENTURY
}

At the beginning of the 18th century a new player joined the game for the influence and power over the world. From the period of Northern War Russian Empire had entered the political stage, at first as a newcomer, and then as one of its most important actors. It was just the beginning of a farreaching process - an expansion which lasted up to the eighties of our century.

A change of special importance occurred during the first half of the 19th century. During this period in Russia's foreign politics an important step was made from regional to global activity. It is true that political, economic, and military conditions of this process should not be disregarded, but in my opinion such an extension of the field of activity had to be closely connected with the state of minds of the ruling class. It required the change of political imagination. Thus, it would be interesting to describe a geographical range of Russian political imagination on the eve of the Great Change.

The basic problems of Russian foreign politics are described in many historical works. I will attempt, therefore, to answer some questions which seem quite new to me: what was the shape of the political arena as seen by the ruler and the diplomats of the Empire? What was the geographical horison of their political plans?

Searching for the answers we should first appoint the limits of the world which was known to the contermporaries. It would enable us to stake out the outlines of possible space of the rivalry.

The geographical horison of people of the Enlightenment was quite wide. Scientific expeditions, including Russian, (e.g. Bering, Łaptiev, Krusenstern) played an important role. Thanks to them the contemporary politicians got on their maps contours of almost all seas and continents. Only some polar areas of oceans and interiors of cointinents were unknown (the interior of Africa, Australia, north-eastern part of North America, southeastern part of Asia).

In spite of this scientific activity, the role of geography was rather insig- 
nificant in the education of the youth of that time (usually this subject was connected with history). Geographical education of the Russian elite was silimar to other European ones. Although some achievements of scientific expeditions to which rulers contributed influenced the interests in geography, there was a certain lack of practice. I think that a long tradition of overseas expansion had to develop geographical horisons of British, French, or Dutch elites to a greater extent. At the present stage of my study it is difficult to make such a comparison between the elites of Russia and Western Europe. I suppose that we could find a common background of geographical knowlege and a lot of important differences in particulars.

The geographical range of Russian elite's political imagination was affected by expansion of the empire during the 18th century. The process was directed towards the West (1721-1795 - access to the Baltic Sea coast; 1772-1795 annexation of the eastern provinces of Poland) and towards the South (1696-1787 - access to the Black Sea and the Caspian Sea coasts). Military power and diplomatic skills helped to achieve the most important goal of Russia's foreign policy, i.e. the approach to the seas. It was a fact of great strategic importance which allowed Russia to pass from border politics to the continental one. New conquests provided new prospects. From that time onwards, an extension of geographical perspective of the Russian politics could be clearly observed. It is proved e.g. by military activity - until about 1794 Russian army had operated only in the area of adjoining countries (Persia, Ottoman Empire, Austria, Poland, Prussia). During the war of 1797-1799 Russian units fought in Italy (Suvorov), Switzerland (Rimski-Korsakov) and its navy acted in the Mediterranean Sea (Ushakov).

Political and economic reasons caused a retreat of Russia from European military conflicts, but in was not connected with an isolationism. The empire continued to be one of the most important actors on the political stage of the continent.

The geographical range of Russian politicians' interests could be delimited by an analysis of the activity of the state and political projects elaborated by its politicians. More thorough study of sources is planned, but now I would like to present only some general observations and problems which should be solved.

Considering geographical extent of Russian political activity we could observe its two main directions: West and South.

The western direction included European continent, basins of the Baltic and Meditterranean Seas and a part of northern coasts of Africa (for some political "reasons" I decided to include Egypt into the matter under discussion).

The West was the area of the most intensive political activity of Russia. It was the time of struggle between the powers of ancien regime and revolutionary France. Hegemony and new shape of political stage played an im- 
portant role in spite of serious ideological differences. France, Great Britain, Austria and Prussia composed the group of active participants of the game. The stake were territorial captures and influence in the controversial areas: in Germany, Italy, and part of a large but weak Ottoman Empire (Greece, Balkans, Egypt). These regions were of particular interest to Russian foreign policy. It was expressed by its active participation in the negotiations for a new territorial shape of German states (the question of (the so-called indemnity), political support for the rulers of Naples and Sardinia, and stable resistance to French attempts to penetrate the Balkans (Albania, Hercegovina, Greece, i.e. Russian protectorate upon the Republic of Seven Islands).

Southern direction included an area of Caucasian borderland between Russia, Persia and Turkey. An incorporation of eastern Georgia in 1801 caused that Russia entered into sustained conflict. Each of the three rivals aspired to domination over the small states (Megrelia, Imeretia, Armenia, Azerbaidzhan khans) and mountain tribes, which were hostile to each other and used to change their political orientation all the time. The war with Persia broke out in 1804 , but it was not a surprise due to old controversies. In spite of a small number of Russian troops in Caucasus, the situation in that region was also an object of special interest to the Russian ruling class.

There were also some relatively new regions which gained some significance in Russian foreign policy in the above mentioned period. Their role in the political activity of the empire was certainly of smaller degree than the role of the areas mentioned above. Anyhow, their presence in Russian political thought and practice may be treated as a proof of the broadening of the geographical extent of political imagination.

In 1803 the diplomatic mission led by J. Golovkin was sent to China. Diplomatic contacts between Peking and Petersburg were rather occassional. The main aim of Golovkin's mission was to establish constant and friendly relationships.

The political interests of Petersburg focused also on quite strong states of Central Asia - Bukhara and Khiva. A diplomatic mission to that region was planned at the end of 1802. An instruction prepared for lieutenant Gaverdowskj proves that the knowledge of the above-mentioned area was rather small in Russia. The purpose of the mission was to provide information on political situation, frontiers, economy, trade routes etc. The lack of such data surely limited the possibilities of political activity in that region.

Almost at the same time, in 1803, Russian government intended to send a mission to Japan (Rezanov).

The other regions of Asia were less important for Russian diplomacy. Afghanistan, Tibet or India were mentioned in reports and memorials very rarely and usually in context of the activity of Russian merchants. It is characteristic that references to these countries appear as a rule in reports 
of N. Rumiancew, contemporary minister of commerce. Economic activity of the individuals outdistanced the political activity of the state.

It is easy to observe that there were enormous spaces of three continents outside Russian activity and political planning of that time. North and South America remained in the sphere of influence of Great Britain, Spain and Portugal. The United States of America had had some significance in the policy of Catherine the Great, but then in changed circumstances its role was rather small. The coastline of Alaska, counted among the imperial possessions, appeared as the unknown, wild territory of exotic, altough remu-nerative, commercial activity and scientific researches.

Africa, a continent unknown to all Europeans, did not attract attention for many reasons. One of them was the weakness of the Russian fleet blocked in the Baltic and Mediterranean, the other - good relations with Great Britain controlling the ocean route to India. The coasts of Africa were treated as its sphere of influence.

The geographical extent of Russian politicians' interests could be described approximately as a circle of radius of about 2-3 thousands of kilometers from Petersburg. That area contained the basic directions: Western and Southern. The objects of Russian expansion in the years to come, i.e. Khiva, Bukhara, Kokand etc., were located in the neighbourhood of its borders.

Such a radius of political interests was first of all a result of the understanding the principal strategic aims of the empire. The region which I used to call the "Western area" was a contemporary political centre of the world for European states. Great Game in that region was still far from the end. It was not the world of a broad extent. The main rivalry of European powers still rarely went beyond the limits of the Old Continent.

It seems to me that the geographical extent of Russian political interests was also connected with the problem of space and time. The influence of these factors on mentality and consciousness of contemporary people is sometimes underestimated nowadays.

The perception of time and space is related to the question of transmitting information, important from the politicians' point of view. The communication and ways of transmission were still very imperfect. The couriers travelled within the "known world" at a speed of tens kilometers per hour. News from European capitals usually reached Petersburg after 7 to 20 days. The travel of a special messenger, who was sent to Irkutsk in 1797 lasted 34 days. The politicians needed also some time to receive or send orders, instructions etc. We can try to reconstruct a pattern of policy making of that time: the 1st phase: event - report - transmission to the centre (e.g. 7-30 days); the 2 nd phase: analysis - decision (e.g. 2-7 days) - transmission of orders (next 7-30 days). All these circumstances resulted in the different perception of time and space. There is no doubt that the duration of the transmitting of information had an influence on the world outlook 
and political activity. Perhaps this was one of the reasons why the basic political activity of the states of that period was concentrated on the territories nearby their own decision-making centre (a few "weeks of transmission")? The other areas could be perceived as a distant, imperceptible world, which was not subjected to political planning. Political imagination may be developed on the basis of realities and recognizable areas. The lack of data could produce fantasies.

Therefore, political activity was concentrated on the regions which were known and close to the centre. Naturally, it was also a result of difficult situation in Europe and southern borderland of the empire.

The regions outside the main circle were unknown or known insufficiently. The lack of information or interests caused passiveness or activity reduced to reconnaissance of small scale.

The cause of Cossacks' expedition to India ordered by Paul I seems to be very typical of that world outlook. Many historians emphasize that tsar's decision, connected with an attempt to establish close cooperation with France against Great Britain, terrified the imperial elite - it was taken as a decisive proof of irresponsibility or madness of the ruler. In his first order issued just a few hours after his father's death, Alexander I called the troops to come back. An unusual haste was caused by his will to mitigate the conflict with Great Britain. It seems to me that besides diplomatic reasons, his intention was to separate himself from the most controversial decision of his predecessor. Cossacks' expedition to India was an expedition beyond the limits of political imagination, that was why it provoked a real shock. The revocation of an order of the "mad" tsar was a manifestation of realism. It was a kind of a symbolical return to the world of familar political grounds. A greater extent of political imagination could terrify the contemporaries.

Therefore the world of Russian politicians was not broad. The areas of their activity concentrated relatively near the centre, which faciliated transmission of information and orders. Beyond the limits of the politicians' world there were the worlds of merchants, scientists and adventurers. The time of global policy was still to come. 
